\title{
VIRGINITAS DAN INTENSI SEKS PRA NIKAH: PERAN RELIGIUSITAS SEBAGAI VARIABEL MODERATOR PADA PERESTA DIDIK PEREMPUAN
}

\author{
Radite Wanodya ${ }^{1}$ \\ Retno Dwiyanti ${ }^{2}$
}

\begin{abstract}
Indonesia is famous for its Eastern culture that is still maintained until today including the norms of religion, modesty, morality, and legal. This research aimed to test the effect of virginity towards premarital sex intention with religiosity as the moderator variable on female students of School X in Banyumas Regency. The method of this research was quantitative and the subjects involved 108 female students in School X. The data were collected using the virginity scale instrument, premarital sex intention scale, and religiosity scale. The coefficient validity item on the scale of virginity moved from 0.160 to0.737, coefficient validity of premarital sex intention moved from $0.202-0.782$ and coefficient validity of the religiosity scale moved from $0.690-0.719$. Coefficient reliability on the scale of virginity was 0.725 , the coefficient reliability on the scale of premarital sex intention was 0.717 , and coefficient reliability on the scale of religiosity was 0.706 . The results showed that there was an effect of virginity towards premarital sex intention with religiosity as the moderator variable. Based on the analysis results, the coefficient determination of Rsquare was 0.494 which meant virginity and religiosity contributed $49.4 \%$ effective support toward premarital sex intention and $51.6 \%$ external support from other factors (factors not studied).
\end{abstract}

Keywords: Virginity; Premarital Sex intention; Religiosity

\begin{abstract}
ABSTRAK
Indonesia terkenal dengan adat ketimurannya yang masih dipertahankan hingga saat ini, termasuk norma-norma yang diatur di dalamnya seperti norma agama, norma kesopanan, norma kesusilaan, dan norma hukum. Penelitian ini bertujuan untuk menguji pengaruh virginitas terhadap intensi seks pra nikah dengan religiuitas sebagai variabel moderator pada peserta didik perempuan di sekolah X Kabupaten Banyumas. Metode dalam penelitian ini menggunakan pendekatan kuantitatif. Subjek penelitian berjumlah 108 peserta didik perempuan di sekolah X Kabupaten Banyumas. Data dikumpulkan menggunakan instrumen skala virginitas, skala intensi seks pra nikah dan skala religiusitas. Koefisien validitas item pada skala virginitas bergerak dari 0,160 sampai 0,737, koefisien validitas intensi seks pra nikah bergerak dari 0,202 - 0,782 dan koefisien validitas skala religiusitas bergerak dari 0,690 - 0,719. Koefisien reliabilitas skala virginitas sebesar 0,725 kemudian koefisien reliabilitas skala intensi seks pra nikah sebesar 0,717 dan koefisien reliabilitas skala religiusitas sebesar 0,706. Hasil dari penelitian ini menunjukan bahwa terdapat pengaruh virginitas terhadap intensi seks pra nikah dengan religiusitas sebagai variabel moderator. Berdasarkan hasil analisis juga diperoleh hasil koefisien determinasi $\mathrm{R}_{\text {square }}$ sebesar 0,494 nilai tersebut mengandung arti bahwa dalam penelitian ini virginity value dan religiusitas memberikan sumbangan efektif sebesar $49,4 \%$ terhadap intensi seks pra nikah, sedangkan 51,6\% merupakan sumbangan dari dari faktor lain (faktor yang tidak diteliti).
\end{abstract}

Kata kunci: Virginitas; Intensi Seks Pra Nikah; Religiusitas.

\section{PENDAHULUAN}

Indonesia adalah Negara Kesatuan Republik yang mayoritas penduduknya memeluk agama Islam, meski di Indonesia sendiri sebenarnya terdapat empat agama lain yang sudah

\footnotetext{
${ }^{1}$ Fakultas Psikologi, Universitas Muhammadiyah Purwokerto, raditewanodya@yahoo.co.id

${ }^{2}$ Fakultas Psikologi, Universitas Muhammadiyah Purwokerto
} 
resmi di akui diantaranya ada Budha, Hindu, Kristen, dan Kong Hu Chu. Sesuai dengan adat dan budaya ke-timurannya tentu saja semua hal sudah diatur dalam norma-norma masyarakat pada umumnya. Mulai dari norma agama, norma kesopanan, norma kesusilaan, bahkan sampai norma hukum'pun sudah diatur didalamnya. Namun sayangnya masih banyak ditemukan kasus pelanggaran norma, dan oknum pelakunya tersebut di dominasi oleh kalangan peserta didik yang masih duduk dibangku sekolah.

Entah karena kurangnya edukasi atau memang kurangnya kesadaran diri dalam menegakkan serta mengalamalkan nilai-nilai moral yang seharusnya. Selain itu figur orangtua, tenaga pengajar, serta lingkungan juga ternyata sangat berpengaruh terhadap pembentukan moral peserta didik dikemudian hari. Menurut pasal 1 ayat 4 UU RI No. 20 Tahun 2003 tentang sistem pendidikan Nasional, peserta didik adalah anggota masyarakat yang berusaha mengembangkan dirinya melalui proses pendidikan pada jalur jenjang dan jenis pendidikan tertentu.

Para peserta didik ini sedang ada dalam tahap perkembangan usia remaja yakni dikatakan Hurlock (1999) rentang usia remaja dimulai usia 13-21 tahun, sebagian besar remaja biasanya akan mulai merasa bahwa pada fase ini mereka sudah berhak melakukan apapun tanpa seizin orang tuanya termasuk menjajal hal-hal baru yang diluar batas. Bagi sebagian peserta didik menganggap bahwa pada tahap perkembangan ini merupakan bagian dari pembuka kebebasan bagi mereka untuk melakukan apapun kegiatan yang mereka ingin tahu lebih dalam, padahal peran orangtua dan guru di sekolah sebenarnya masih diperlukan dalam hal pengontrolan diri peserta didik.

Berdasarkan data Perkumpulan Keluarga Berencana Indonesia (PKBI) Jawa Tengah, pada tahun 2012 remaja yang melakukan hubungan seks pra nikah sebanyak 863 orang, hamil di luar nikah 452 orang, infeksi menular seksual 283 orang, mastrubasi 337 orang, aborsi 244 orang. Kasus ini meningkat dari tahun 2009 dimana kasus remaja yang melakukan seks pra nikah sebanyak 765 orang, hamil diluar nikah 367 orang, terinfeksi menular seksual 275 orang, mastrubasi 322 orang, aborsi 166 orang. Survey yang dilakukan oleh Youth Center Pilar PKBI Jawa Tengah tahun 2012 dengan 99 responden siswa SMA di Semarang didapatkan data berpegangan tangan $82,8 \%$, berpelukan $68,7 \%$, mencium pipi $64,6 \%$, berciuman $62,6 \%$, saling meraba badan dan kelamin 32,2\%, melakukan petting 20,2\%, melakukan oral seks $8,1 \%$, melakukan hubungan seks vagina 14,1\% (Pilar, 2012).

Pada tingkat Jawa Tengah, khususnya Kabupaten Banyumas jumlah penduduk usia remaja mencapai 261.760 (16,10\%) jiwa dari keseluruhan penduduk di Kabupaten Banyumas. Berdasarkan data dari Pengadilan Agama Purwokerto menunjukkan bahwa terdapat 113 pemberian surat dispensasi nikah pada tahun 2016. Surat dispensasi nikah hanya diberikan pada mereka yang belum memiliki cukup umur sesuai undang-undang perkawinanatau biasanya yang masih berstatus sebagai peserta didik, akan tetapi ingin melangsungkan penikahan, hal ini dikarenakan pihak dari perempuan telah hamil terlebih dahulu, dan rentang usianya ada pada jenjang pendidikan SMP SMA. Hal ini menunjukan bahwa perilaku seks pra nikah sudah menjadi permasalahan yang cukup genting di lingkungan masyarakat dan harus segera di usut sebab-akibatnya.

Peserta didik biasanya akan berusaha menemukan jati dirinya, cintanya, kemudian mencari apa yang menjadi passionnya, dan ada banyak rasa keingintahuannya untuk mengeksplore berbagai macam sisi tentang dunia. Entah karena perkembangan zaman yang 
semakin modern sehinga rasa malu maupun rasa bersalah pada peserta didik yang melakukan pelanggaran norma jutsru menjadi hal dianggap wajar atau lumprah terjadi. Peserta didik menjadi merasa nyaman-nyaman saja ketika melakukan suatu pelanggaran norma, bahkan tanpa rasa bersalah karena peserta didik menganggap pelanggaran sudah menjadi hal biasa yang memang banyak terjadi di lingkungan peserta didik terutama pada lingkungan pergaulan.

Salah satu pelanggaran norma kesusilaan yang kerap dilakukan oleh peserta didik adalah maraknya kegiatan yang mengarah pada intensi seks pra nikah. Latar belakang yang memperkuat penelitian ini yaitu adanya kasus video viral yang melibatkan sepasang peserta didik. Dalam kasus terseut beredar video tentang tindak asusila yang merujuk pada intensi seks pra nikah yang dilakukan secara terbuka terang-terangan di tempat umum. Dan dalam video tersebut sepasang peserta didik tersebut masih mengenakan pakaian lengkap seragam identitas sekolah.

Tujuan dari penelitian ini adalah untuk mengetahui apakah ada pengaruh virginitas terhadap intensi seks pra nikah dengan religiusitas sebagai variabel moderator pada peserta didik perempuan di sekolah X kabupaten Banyumas. Kemudian manfaat dilakukannya penelitian ini adalah sebagai bahan pengembangan untuk ilmu psikologi selanjutnya, serta memberikan informasi kepada pembaca khususnya peserta didik untuk lebih memaknai tentang pentingnya menjaga virginitas dengan religusitas sebagai tameng pelindung agar sebisa mungkin menghindari kegiatan yang merujuk pada intensi seks pra nikah.

Hal yang mendasari intensi seks pra nikah lantaran pada usia ini proses reproduksi seksual peserta didik mulai aktif dan matang, sehingga menyebabkan munculnya minat seksual dan keingintahuan yang lebih tinggi tentang seksualitas. Hal ini menjadikan peserta didik sangat rentan mengarah pada intensi seks pranikah (Muzayyanah, 2008). Intensi seks pra nikah adalah kegiatan yang mengarah pada munculnya tindakan berkelanjutan yang berhubungan dengan dorongan seksual dengan lawan jenis maupun sesama jenis yang dilakukan sebelum adanya pernikahan (Sarwono, 2008).

Kemudian dampak dari intensi seks pra nikah tidak hanya berdampak pada fisik saja, seperti kesehatan reproduksi, infeksi penyakit menular seksual (PMS), peluang kemungkinan hamil tanpa persiapan, dan bahkan ada kemungkinan tindakan aborsi di kemudian harinya. Tentunya tidak lepas dari dampak atau kerugian yang terbesar ada pada peserta didik perempuan, apabila sampai dilakukannya penetrasi penis kedalam vagina maka keperawanan perempuan bisa saja dikatakan hilang. Sementara itu di Indonesia sebagian masyarakat masih menganggap bahwa virginitas merupakan hal yang utlak harus dijaga sampai tiba saatnya menikah.

Menurut Carpenter (2005) virginitas adalah sebuah hal yang mutlak dan wajib harus dijaga oleh seorang perempuan hingga ia menikah kelak. Apabila tidak dapat menjaganya maka dapat dikatakan harga diri dari perempuan tersebut akan jatuh di mata masyarakat maupun di depan suaminya. Bahkan virginitas sudah menjadi hal yang dirasa teramat agung dan suci, semenjak dahulu diakui sebagai simbol perbedaan perempuan shalihah dan kurang shalihah. Virginitas adalah keyakinan tentang keperawanan yang berfungsi sebagai pedoman untuk membantu individu membuat keputusan apakah akan tetap perawan atau untuk mendapatkan pasangan perawan (Patmawati, 2013).

Selain ditinjau dari stigma masyarakat tentang keperawanan, rupanya masih banyak pula peserta didik yang memang kurang pemahaman soal agama dan moral yang mengakibatkan munculnya penafsiran, persepsi dan sikap yang kurang tepat dalam memandang kegiatan intensi seks pranikah. Menurut Jalaludin (2008) religiusitas adalah keberagaman yaitu 
suatu keadaan yang ada dalam diri seseorang untuk mendorongnya untuk bertingkah laku sesuai dengan ketaatannya terhadap agama. Sedangkan menurut Ancok dan Suroso (2011) religiusitas merupakan perilaku terhadap agama berupa penghayatan terhadap nilai-nilai agama melalui ketaatan dalam menjalankan ibadah ritual, juga dengan keyakinan, pengalaman, dan pengetahuan mengenai agama yang dianutnya

Hipotesis pada penelitian ini yaitu terdapat pengaruh virginitas terhadap intensi seks pra nikah dan terdapat pengaruh virginitas terhadap intensi seks pra nikah dengan religiusitas sebagai variabel moderator pada peserta didik perempuan di sekolah X kabupaten Banyumas.

\section{METODE PENELITIAN}

Sampel dalam penelitian ini berjumlah 108 peserta didik perempuan di sekolah $\mathrm{X}$ kabupaten Banyumas. Metode pengumpulan data dalam penelitian ini menggunakan skala virginitas, skala intensi seks pra nikah dan skala religiusitas. Jenis skala yang digunakan adalah skala likert. Skala likert digunakan untuk mengukur sikap, pendapat dan persepsi seseorang atau sekelompok orang tentang fenomena sosial (Sugiyono, 2014). Skala tersebut disusun berdasarkan pengembangan indikator perilaku sesuai dengan aspek - aspek yang melekat pada masing - masing variabel. Menurut (Carpenter, 2005) aspek - aspek virginitas terdiri dari: Fisiologis, Sosiologis, dan Psikologis. Sedangkan aspek-aspek intensi seks pra nikah menurut (Azjen, 2005) meliputi: Tindakan, Sasaran, Konteks, dan Waktu. Kemudian aspek-aspek religiusitas menurut (Glok dan Stark, 1988) meliputi: Keyakinan, Praktik Agama, Pengalaman, Pengetahuan, dan Knsekuensi. Berdasarkan hasil uji reliabilitas skala virginitas diperoleh nilai $\alpha$ sebesar 0,725 . Untuk nilai $\alpha$ pada skala intensi seks pra nikah yaitu 0,717 Sedangkan untuk nilai $\alpha$ pada religiusitas yaitu 0,706 .

\section{HASIL}

Analisis data yang digunakan dalam penelitian ini adalah moderating regression analysis dengan menggunakan data kuantitatif. Metode uji statistik yang digunakan adalah menggunakan program komputer SPSS for windows versi 23.00.

\section{Uji Deskriptif}

Hasil uji deskriptif diketahui dari 108 jumlah responden memiliki skor virginitas yang berbeda-beda, yaitu terdapat 2 responden tergolong sangat tinggi dengan prosentase $1,8 \%$, sebanyak 35 responden tergolong tinggi dengan prosentase $32,4 \%$, sebanyak 40 responden tergolong sedang dengan prosentase $37 \%$, sebanyak 30 responden tergolong rendah dengan prosentase $27,7 \%$, dan sebanyak 1 responden tergolong sangat rendah dengan prosentase $0,9 \%$.

Hasil uji deskriptif diketahui dari 108 jumlah responden memiliki skor intensi seks pra nikah yang berbeda-beda, yaitu terdapat 6 responden tergolong sangat tinggi dengan prosentase $5,5 \%$, sebanyak 19 responden tergolong tinggi dengan prosentase $17,5 \%$, sebanyak 60 responden tergolong sedang dengan prosentase 55,5\%, sebanyak 18 responden tergolong rendah dengan prosentase $16,5 \%$, dan sebanyak 5 responden tergolong sangat rendah dengan prosentase $4,6 \%$. 
Hasil uji deskriptif diketahui dari 108 jumlah responden memiliki skor religiusitas yang berbeda-beda, yaitu terdapat 4 responden tergolong sangat tinggi dengan prosentase 3,7\%, sebanyak 35 responden tergolong tinggi dengan prosentase 32,4\%, sebanyak 36 responden tergolong sedang dengan prosentase $33,3 \%$, sebanyak 30 responden tergolong rendah dengan prosentase $27,7 \%$, dan sebanyak 3 responden tergolong sangat rendah dengan prosentase $2,7 \%$.

\section{Uji Hipotesis}

Penelitian ini untuk mengetahui pengaruh virginitas terhadap intensi seks pra nikah. Hasil analisis data dilampirkan dalam tabel berikut ini:

\section{Tabel 3. Uji Hipotesis 1}

\begin{tabular}{|c|c|c|c|c|c|c|c|}
\hline Variabel & & $\mathbf{F}$ & B & $t$ & Rsquare & $\mathbf{P}$ & Ket. \\
\hline $\begin{array}{l}\text { Virginitas } \rightarrow \\
\text { Seks Pra Nikah }\end{array}$ & Intensi & 8,456 & & & 074 & 0,000 & Signifikan \\
\hline $\begin{array}{l}\text { (Constant) } \\
\text { Virqinitas }\end{array}$ & & & $\begin{array}{r}112,767 \\
.245\end{array}$ & $\begin{array}{l}7,957 \\
2,908\end{array}$ & & 0,000 & \\
\hline
\end{tabular}

Hasil uji hipotesis untuk pengaruh virginity value terhadap intensi seks pra nikah diperoleh nilai $F_{\text {hitung }} 8,456$. Kemudian diperoleh nilai probilitas sig. $(p)=0,000(p<0,01)$ dan $t_{\text {hitung }} 2,908$. Berdasarkan hasil tersebut dapat disimpulkan maka hipotesis diterima yaitu terdapat pengaruh yang signifikan virginitas terhadap intensi seks pra nikah. Dalam penelitian ini diperoleh hasil persamaan garis regresi yaitu $(y=a+b x)$ maka meghasilkan $y=112,767+$ $0,245 \mathrm{x}$. Koefisien b dinamakan koefisien arah regresi dan menyatakan perubahan rata-rata variabel Y untuk setiap perubahan variabel X sebesar satu satuan.

Perubahan ini merupakan pertambahan bila $b$ bertanda positif dan penurunan bila $b$ bertanda negatif. Dengan ini dapat disimpulkan bahwa intensi seks pra nikah akan berubah sebesar 0,245 untuk setiap perubahan yang terjadi pada virginity value. Berdasarkan hasil analisis juga diperoleh hasil koefisien determinasi $\mathbf{R}_{\text {square }}$ sebesar 0,074. Nilai tersebut mengandung arti bahwa dalam penelitian virginity value memberikan sumbangan efektif sebesar 7,4\% terhadap intensi seks pra nikah, sedangkan 83,6\% merupakan sumbangan dari faktor lain (faktor yang tidak diteliti).

Penelitian ini untuk mengetahui pengaruh virginitas terhadap intensi seks pra nikah dengan religiusitas sebagai variabel moderator. Hasil analisis data dilampirkan dalam tabel berikut ini:

Tabel 4. Uji Hipotesis 2

\begin{tabular}{lrrrrrc}
\hline Variabel & F & B & t & Rsquare & P & Ket. \\
\hline $\begin{array}{l}\text { Virginitas } \rightarrow \text { Intensi } \\
\text { Seks Pra }\end{array}$ Nikah - & 44,244 & & &, 697 & 0,000 & Signifikan \\
Religiusitas & & & & & & \\
& & & & & & \\
(Constant) & & 19,643 & 4,510 & & 0,000 & \\
Virginitas &, 226 & 2,853 & & & \\
Religiusitas &, 846 & 3,341 & & & \\
X1_X2 & & 601 & 10,745 & & & \\
\hline
\end{tabular}


Hasil uji hipotesis untuk pengaruh virginitas terhadap intensi seks pra nikah dengan religiusitas sebagai variabel moderator diperoleh nilai $F_{\text {hitung }} 44,244$. $t_{\text {hitung }}$ pada variabel $X=$ 2,853 Dan variabel $M=3,341$ kemudian diperoleh nilai probilitas sig. $(p)=0,000(p<0,01)$. Berdasarkan hasil tersebut dapat disimpulkan maka hipotesis diterima yaitu terdapat pengaruh yang signifikan virginitas terhadap intensi seks pra nikah dengan religiusitas sebagai variabel moderator. Dalam penelitian ini diperoleh hasil persamaan garis regresi yaitu $(\mathrm{y}=\mathrm{a}+\mathrm{bX}+\mathrm{cM}$ $+\mathrm{d}(\mathrm{x} 1 . \mathrm{m}))$ yaitu $\mathrm{y}=19,634+0,226 \mathrm{x}+0,842 \mathrm{~m}+0,601(\mathrm{x} 1 . \mathrm{m})$. Koefisien $\mathrm{b}$ dan $\mathrm{c}$ dinamakan koefisien arah regresi dan menyatakan perubahan rata-rata variabel intensi seks pra nikah peserta didik untuk setiap perubahan variabel virginity value dan religiusitas.

Perubahan ini merupakan pertambahan bila $b$ dan $c$ bertanda positif dan penurunan bila $b$ dan c bertanda negatif. Dengan ini dapat disimpulkan bahwa intensi seks pra nikah peserta didik perempuan di sekolah X Kabupaten Banyumas akan berubah sebesar 0,877 untuk setiap perubahan yang terjadi pada religiusitas dan 0,251 untuk setiap perubahan yang terjadi pada virginitas. Berdasarkan hasil analisis juga diperoleh hasil koefisien determinasi nilai $\mathbf{R}_{\text {square }}$ pada hipotesis I sebesar 0,074 atau 7,4\% sedangkan pada hipotesis II menghasilkan nilai $\mathbf{R}_{\text {square }}$ sebesar 0,697 atau 69,7\%. Dengan melihat hasil ketiga hipotesis tersebut dapat disimpulkan bahwa dengan adanya religiusitas sebagai variabel moderator akan dapat memperkuat pengaruh virginitas terhadap intensi seks pra nikah.

\section{PEMBAHASAN}

Pada penelitian ini mengungkap pengaruh virginitas terhadap intensi seks pra nikah pada peserta didik perempuan di sekolah X Kabupaten Banyumas. Berdasarkan uji regresi, pengaruh virginitas terhadap intensi seks pra nikah pada peserta didik perempuan di sekolah $\mathrm{X}$ kabupaten Banyumas, dengan taraf signifikansi 5\% diperoleh $\mathrm{F}_{\text {hitung }}=8,456$ dan $\mathrm{t}_{\text {hitung }}=2,908$. Kemudian diperoleh nilai probabilitas sig. $(\mathrm{p})=0,000(\mathrm{P}<0,05)$. Hal ini menyatakan bahwa hipotesis diterima yaitu adanya pengaruh yang signifikan pada virginitas terhadap intensi seks pra nikah. Artinya semakin tinggi virginitas maka akan menekan tingginya intensi seks pra nikah.

Virginitas terbukti dapat mempengaruh intensi seks pra nikah seseorang (Zou, 1983). Maksudnya adalah seseorang yang memiliki nilai tinggi terhadap virginitas akan cenderung berperilaku menjaga keperawanannya. Otomatis orang tersebut akan menghindari bagaimana caranya agar terhindar ataupun menjauhi hal-hal maupun tindakan apapun yang mengarah pada intensi seks pra nikah. Hal ini sering terjadi pada peserta didik yang sedang dalam fase peralihan, peserta didik akan segan mendekati intensi seks pra nikah jika virginity value peserta didik dirasa cukup tinggi.

Koefisien b dinamakan koefisien arah regresi dan menyatakan perubahan rata - rata variabel Y untuk setiap perubahan variabel X. Dengan ini dapat disimpulkan bahwa intensi seks pra nikah akan berubah sebesar sebesar 0,245 untuk setiap perubahan yang terjadi pada virginitas. Hasil koefisien determinasi $\mathbf{R}_{\text {square }}$ sebesar 0,074. Nilai tersebut mengandung arti bahwa dalam penelitian virginitas memberikan sumbangan efektif sebesar $7,4 \%$ terhadap intensi seks pra nikah, sedangkan 92,6\% merupakan sumbangan dari faktor lain (faktor yang tidak diteliti). Hasil tersebut didukung dengan hasil penelitian yang dilakukan oleh Rizkika Ayu Fitriani (2017) yang menyatakan bahwa virginitas seseorang sangat berpengaruh terhadap intensi seks pra nikahnya. Semakin tinggi persepsi seseorang terhadap virginitas maka akan semakin rendah intensi seks pra nikah yang dilakukannya. 
Seseorang yang mempu mempertahankan keperawanannya sampai batas waktu yang tepat maka menandakan seseorang tersebut memiliki nilai yang tinggi atas kemurnian dirinya sendiri, seseorang tersebut dipastikan mampu mengahargai kepunyaan diri sendiri sebab seseorang tersebut tahu jika nilai keperawanan tidak tertandingi dengan hal apapun, apalagi yang hanya bersifat main-main seperti intensi seks pra nikah atau diluar ikatan yang sah (Carpenter, 2005).

Berdasarkan hasil penelitian yang telah dilakukan oleh (Desi dan Sutanto, 2015) bahwa terdapat hubungan yang signifikan antara virginitas terhadap intensi seks pra nikah pada remaja tingat Sekolah Menengah Atas (SMA) dengan koefisien relasi parsial (r) antara virginitas terhadap intensi seks pra nikah sebesar 0,670. Dan nilai signifikansi 0,000 $<0,05$. Hasil tersebut menunjukan terdapat hubungan yang signifikansi antara virginitas terhadap intensi seks pra nikah. Seseorang yang memiliki virginitas tinggi artinya dapat menekan angka intensi seks pra nikah atau setidaknya dapat meminimalisir hal tersebut.

Kemudian penelitian ini juga mengungkap pengaruh virginitas terhadap intensi seks pra nikah dengan religiusitas sebagai variabel moderator pada peserta didik perempuan di sekolah $\mathrm{X}$ kabupaten Banyumas. Berdasarkan uji regresi, pengaruh virginitas terhadap intensi seks pra nikah dengan religiusitas sebagai variabel moderator pada peserta didik perempuan di sekolah $\mathrm{X}$ kabupaten Banyumas, dengan taraf signifikansi 5\% diperoleh $\mathrm{F}_{\text {hitung }}=44,244$ dan $t_{\text {hitung }}=$ 10,745. Kemudian diperoleh nilai probabilitas sig. $(p)=0,000(p<0,05$. Hal ini menyatakan bahwa hipotesis diterima yaitu adanya pengaruh yang signifikan pada virginitas terhadap intensi seks pra nikah dengan religiusitas sebagai variabel moderator. Artinya dengan adanya religiusitas sebagai variabel moderator akan dapat memperkuat pengaruh virginitas terhadap intensi seks pra nikah.

Hal ini dibuktikan dengan hasil koefisien determinasi $R_{\text {square }}$ sebesar 0,493 . Nilai tersebut mengandung arti bahwa dalam penelitian religiusitas memberikan sumbangan efektif sebesar 49,3\% terhadap intensi seks pra nikah, sedangkan 50,7\% merupakan sumbangan dari faktor lain (faktor yang tidak diteliti). Pada peserta didik khususnya untuk sekolah-sekolah yang sudah berbasis islami akan lebih kuat dan dalam religiusitas yang ditanamkan pada peserta didiknya, hal ini sangat berguna sebagai tameng dan pengontrol agar peserta didik tidak dengan mudahnya tersejurumus pada intensi seks pra nikah (Anis Rosidah, 2012). Serta didukung dengan penelitian yang dilakukan oleh Zou (1983) yang menyatakan virginitas dan religiusitas dapat mempengaruhi intensi seks pra nikah sebesar 53\% dan sisanya sebesar 47\% merupakan faktor lain (faktor yang tidak diteliti dalam penelitian ini).

Koefisien b dan c dinamakan koefisien arah regresi dan menyatakan perubahan rata rata variabel Y untuk setiap perubahan variabel X. Dengan ini dapat disimpulkan bahwa intensi seks pra nikah akan berubah sebesar sebesar 0,877 untuk setiap perubahan yang terjadi pada religiusitas dan 0,251 untuk setiap perubahan yang terjadi pada virginitas. Adanya pengaruh antara ke tiga variabel di atas sesuai dengan penelitian yang dilakukan oleh (Desi dan Sutanto, 2015) bahwa terdapat hubungan yang signifikan antara virginitas dan religiusitas terhadap intensi seks pra nikah pada remaja tingat Sekolah Menengah Atas (SMA) dengan koefisien relasi parsial (r) antara virginitas terhadap intensi seks pra nikah sebesar 0,670. Dan nilai signifikansi $0,000<0,05$. Hasil tersebut menunjukan terdapat hubungan yang signifikansi antara virginitas dan religiuitas terhadap intensi seks pra nikah. Seseorang yang memiliki virginitas tinggi artinya dapat menekan angka intensi seks pra nikah atau setidaknya dapat meminimalisir hal tersebut.

Berdasarkan hasil analisis juga diperoleh hasil koefisien determinasi nilai $\mathrm{R}_{\text {square }}$ pada hipotesis I sebesar 0,074 atau 7,4\% sedangkan pada hipotesis II menghasilkan nilai $\mathbf{R}_{\text {square }}$ sebesar 0,697 atau 69,7\%. Dengan melihat hasil ketiga hipotesis tersebut dapat disimpulkan 
bahwa dengan adanya religiusitas sebagai variabel moderator akan dapat memperkuat pengaruh virginitas terhadap intensi seks pra nikah.

\section{KESIMPULAN}

Berdasarkan hasil penelitian dapat disimpulkan bahwa terdapat pengaruh virginitas terhadap intensi seks pra nikah, dan terdapat perngaruh virginitas terhadap intensi seks pra nikah dengan religiusitas sebagai variabel moderator pada peserta didik perempuan di sekolah $\mathrm{X}$ Kabupaten Banyumas. Keterbatasan dalam penelitian ini adalah dalam proses pengambilan data, salah satunya yaitu tidak dapat berkunjung langsung ke sekolah-sekolah tersebut dikarenakan sedang terjadi pandemi virus Covid-19, hampir seluruh sekolah-sekolah termasuk sekolah X mengubah metode pembelajaran yang awal mulanya di sekolah menjadi metode belajar di rumah. Sehingga peneliti tidak dapat berkunjung secara langsung ke sekolah. Bagi penelitian selanjutnya yang berminat untuk meneliti dengan tema yang sama dengan penelitian ini sebaiknya memperhatikan variabel-variabel lain yang mempengaruhi intensi seks pra nikah.

\section{KEPUSTAKAAN}

Ajzen, I. (2005). Attitudes, Personality, and Behavior. New York: Open University Press.

Ancok, Djamaluddin dan Fuad Nashori Suroso. (2005). Psikologi Islami: Solusi Islam atas Problemproblem Psikologi. Yogyakarta: Pustaka Belajar

Arikunto, S. (2010). Prosedur Penelitian Suatu Pendekatan Praktik. Jakarta: Rineka Cipta

Aulia, M. (2007). Colleration Between Religiosity and Free Sex Behavior at Young Adulthood. Jurnal Ilmiah Gunadarma. 2(1):41-58

Azwar, S (2009). Reliabilitas dan Validitas. Yogyakarta: Pustaka Pelajar

Azniar, M. (2013). Intensi Perilaku Seksual Pranikah Beresiko terhadap Kehamilan Tidak Diinginkan. Jurnal Kesmas. 8(2):143-150

Bhana D., Vimbai Sharon M. (2018). Humhandara and Hujaya: Virginity, Culture, and Gender Inetaquelities Among Adolescents in Zimbabwe. Journal Reproductive Health in SubSaharan Africa. South Africa: University of KwaZulu-Natal, Ashwood

Carpenter, L.M. (2005). Virginity lost: An Intimate Portrait of First Sexual Experiences. New York: New York University

Cooper, Donald R dan Pamela S Chindler. (2001). Bussines Reseach Methode. Boston: McGraw Hill International Edition 
Darmasih, R. (2009). Faktor yang Mempengaruhi Perilaku Seks Pranikah pada Remaja SMA di Surakarta. Skripsi. Surakarta: Fakultas Ilmu Kesehatan Universitas Muhammadiyah Surakarta.

Ertug, Z.K. 2013. Individual Difference on the Importance of Virginity in Turkish Society. International Journal of Human Sciences. Vol 1 no 1. hal 610-620. Turki: Turkish University

Hurlock, E.B (1999). Psikologi perkembangan: suatu pendekatan sepanjang rentang kehidupan ed 5. Jakarta: Erlangga

Jalaluddin. (2002). Psikologi Agama. Jakarta: PT. Raja Grafindo Persada

Kustanti, E.R. (2013). Intensi Melakukan Seks Pranikah Pada Mahasiswa Ditinjau Dari Efektifitas Komunikasi Interpersonal Orangtua-Anak. Semarang: Fakultas Psikologi Universitas Diponegoro

Mangunwijaya, Y. B. 1984. Menumbuhkan Sikap Religius pada Anak. Jakarta: Gramedia.

Muzayyanah. N. (2008). "Dampak perilaku seks bebas bagi kesehatan remaja" diunduh dari http://halalsehat.Com/index.php/RemajaSukses/DAMPAKPERILAKUSEKS-BEBAS-BAGI-KESEHATAN-REMAJA-*.html pada tanggal 13 Mei 2013

Nasution, M. E \& Usman, H. (2007). Proses Penelitian Kuantitatif. Jakarta: Lembaga Penerbit FEUI

PILAR PKBI. (2012). Penelitian perilaku seksual remaja. PKBI Jawa Tengah

PKBI. (2015). Survey perilaku seksual remaja di Semarang. PKBI. Diakses dari http://pkbijateng.or.id/.

Ritandiyono \& Adisti, M.A. (2008). Religiusitas dan Perilaku Seks Bebas pada dewasa awal.

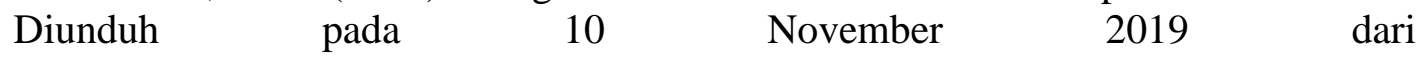
http://ejournal.gunadarma.ac.id/index.php/psiko/article/view/298

Rokeach, M. (1973). The Nature of Human Values. New York. The Free Press

Rosidah, Anis. (2012). Religiusitas, Harga Diri, dan Intensi Seks Pra Nikah Pada Kalangan Remaja. Jurnal Psikologi. 7(2):585-593

Rusmiati, Desi. (2015). Sikap Remaja terhadap Keperawanan dan Intensi Seka Pra Nikah dalam Berpacaran. Jurnal Kesehatan Masyarakat Nasional. 10(1):29-36

Santrock (2003) John W. Adolescence. Perkembangan Remaja. Edisi Keenam. Jakarta: Erlangga 
Sarwono, Sarlito W. \& Eko A. Meinarno. (2012). Psikologi Sosial. Jakarta: Penerbit Salemba Humanika

Sarwono, S. W. (2008). Psikologi Remaja. Jakarta: Balai Pustaka

Slamet, Y. (2009). Pengantar Penelitian Kuantitatif. Surakarta: LPP UNS dan UNS Press

S Rumini, S Sundari. (2004). Perkembangan Anak dan Remaja. Jakarta: Rineka Cipta

Sri Rumini \& Siti Sundari. Perngertian Remaja berbagai Tokoh. Diunduh pada 10 Oktober 2019 pukul 17:34 dari https://belajarpsikologi.com/pengertian-remaja/

Sugiyono. (2009). Metode Penelitian Kuantitatif, Kualitatif, dan R\&D. Bandung: Alfabeta

Taufik dan Anganthi, Nisa Rachmah Nur. (2005). Seksualitas Remaja: Perbedaan Seksualitas Antara Remaja yang Tidak Melakukan Hubungan Seksual dan Remaja yang Melakukan Hubungan Seksual. Jurnal Penelitian Humaniora, Vol. 6, no. 2,: 115 129. Surakarta: Fakultas Psikologi Universitas Muhammadiyah Surakarta

Zou, X. (1989). Virginity and premarital sex in contemporary China. Feminist Studies. 15(2): 279-288.

http://sekolah.data.kemdikbud.go.id/index.php/chome/profil/7D5B0106-5871-4098-B996AF4D6EE78EE3 diakses pada 2 Desember 2019 pukul 23:11

http://www.umm.ac.id/id/pages/jawa-tengah/data-sma-dan-smk-kab-banyumas.html diakses pada 2 Desember 2019 pukul 23: 15 